\title{
A Case of Severe Epistaxis during Pregnancy Treated by Sphenopalatine Artery Ligation
}

\author{
Hyunmo Kang ${ }^{1}$, Hyun-Jin Cho ${ }^{1,2}$, Sea-Yuong Jeon ${ }^{1,2,3}$, and Sang-Wook Kim ${ }^{1,2,3}$ \\ ${ }^{1}$ Department of Otorhinolaryngology, Gyeongsang National University School of Medicine, Jinju; and \\ ${ }^{2}$ Department of Otorhinolaryngology, Gyeongsang National University Hospital, Jinju; and \\ ${ }^{3}$ Institute of Health Sciences, Gyeongsang National University, Jinju, Korea
}

\section{접형구개동맥 결찰술로 치료된 임신 중 후방 비출혈 환자 1예}

강현모 ${ }^{1} \cdot$ 조현진 ${ }^{1,2} \cdot$ 전시영 ${ }^{1,2,3} \cdot$ 김상욱 ${ }^{1,2,3}$

경상대학교병원 이비인후과학교실, 경상대학교 의과대학 이비인후과학교실 ${ }^{2}$, 경상대학교 건강과학연구원 ${ }^{3}$

\author{
Received July 1,2015 \\ Revised September 15, 2015 \\ Accepted September 18, 2015 \\ Address for correspondence \\ Sang-Wook Kim, MD, PhD \\ Department of Otorhinolaryngology, \\ Gyeongsang National \\ University Hospital, \\ 79 Gangnam-ro, \\ Jinju 52727, Korea \\ Tel $+82-55-750-8177$ \\ Fax $+82-55-759-0613$
}

E-mail astroflower77@hanmail.net
Epistaxis is a common disease encountrered in Otorhinolaryngology; however, life-threatening epistaxis during pregnancy is rare, and there are no specific guidelines regarding the management of such patients. We encountered a 38-year-old female patient in the second trimester of her pregnancy, who presented with nosebleeds. No definite focus of bleeding was identified by nasal endoscopy, thus several conservative measures were used to stop nosebleeds including bed rest with head elevation, ice pack application, and nasal packing. Despite such treatments, nosebleeding continued. Endoscopic sphenopalatine artery ligation was conducted under general anesthesia and the results were successful. In obstetric assessment, there was no evidence of fetal distress. The patient delivered a healthy baby at 40 weeks, and there was no recurrence of epistaxis through postoperative 18 months.

Korean J Otorhinolaryngol-Head Neck Surg 2016;59(5):392-5

Key Words Epistaxis · Pregnancy $\cdot$ Surgery $\cdot$ Therapy.

\section{서 론}

비출혈은 이비인후과 영역에서 흔히 볼 수 있는 응급질환 중 하나로 전 인구의 $60 \%$ 가 한 번은 경험한다고 한다. ${ }^{1)}$ 대부 분의 비출혈은 키셀바하 부위(Kiesselbach's plexus)를 비롯한 전방에서 발생하며 보존적 치료로 쉽게 지혈이 가능하지만 드 물게 입원 치료를 요하는 다량의 출혈 양상을 보이기도 한다. ${ }^{2)}$ 후방 비출혈은 고혈압이나 동맥경화 등 기저질환이 있는 고령 의 환자에서 주로 발생하며 전방 비출혈에 비해 출혈량이 많 고 출혈 부위 확인이 쉽지 않은데다 소량이라 할지라도 비인 강을 통해 쉽게 목뒤로 넘어가서 환자가 쉽게 공포감을 느끼 고 당황하기 때문에 치료에 많은 어려움이 있다. 심각한 후방 비출혈의 치료방법으로는 전·후방 비강 패킹, 외경동맥결찰 술, 내악동맥 결찰술 등이 이용되어 왔다. ${ }^{3)}$ 최근에는 비내시경
의 발달로 출혈부위의 정확한 관찰이 가능해졌으며 비내시경 과 전기소작기를 사용하여 직접 지혈하는 후방 내시경 소작 술을 시행하여 $90 \%$ 의 높은 치료성공률을 얻었다는 보고도 있다. ${ }^{4)}$ 임신은 비점막의 혈관분포를 증가시켜 임산부의 경우 비 임신 여성에 비해 비출혈 이환율이 3배 높은 것으로 알려 져 있다. ${ }^{5)}$ 하지만 임산부에서 보존적 치료로 지혈되지 않는 다 량의 후방 비출혈을 보인 예는 세계적으로도 매우 드물며 국 내에서는 보고가 없었다. ${ }^{6)}$ 저자들은 아무런 기저질환이 없는 젊은 임산부에서 수술적 치료가 필요했던 후방 비출혈의 증례 를 경험하였기에 이를 보고하고자 한다.

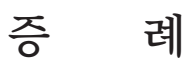

38세의 임신 24주의 산모가 3주 전부터 반복되는 좌측 비 
출혈을 주소로 내원하였다. 코피는 주로 새벽에 났으며 1시간 정도 출혈이 지속되다 멈추는 양상으로 반복되었다. 이전에 특별한 비출혈의 과거력은 없었고, 가족력이나 출혈경향성 질 병도 없었으며 임신으로 인한 철분제 외에 다른 약을 복용하 고 있지 않았다. 내원 1일 전 좌측 비출혈이 지혈되지 않아 타 병원 응급실에서 비강 패킹 후 일시적으로 지혈되었으나 이후 로 2 3시간 간격으로 비출혈이 지속적으로 발생하여 본원으 로 전원되었다. 응급실 내원 당시 심박동수는 $78 \mathrm{bpm}$, 혈압 은 100/60 mm Hg였고 혈색소는 $10.7 \mathrm{~g} / \mathrm{dL}$, 혈소판 $215 \times 10^{3} / \mathrm{L}$ 였으며 간수치는 aspartate aminotransferas는 13U/L, alanine aminotransaminase는 9U/L로 정상이었고 혈액응고검사 결
과는 prothrombin time 12.9초, activated partial thromboplastin time 20.7초로 정상범위였다. 비내시경 검사상 좌측 중비도에 서 출혈소견이 관찰되었으나 정확한 출혈부위는 관찰할 수 없 었다. 중비도에 연고를 도포한 거즈로 비강 패킹을 시행하였고, 패킹 직후에는 출혈이 멈추는 모습을 보였다. 입원 후 침상 안 정 및 좌측 안면부위 얼음찜질을 시행하면서 경과관찰하였으 며, 비강 패킹에 따른 합병증 예방 목적으로 cefazolin $0.5 \mathrm{~g}$ 을 하루 2회 정주하였다. 환자는 내원 1일째 아침에 목뒤로 피가 넘어가는 증상을 호소하였고 혈색소는 $9.6 \mathrm{~g} / \mathrm{dL}$ 로 내원 당일 보다 $1.1 \mathrm{~g} / \mathrm{dL}$ 감소한 소견을 보였다. 구강 검사 시 구인두에 혈성 후비루가 관찰되어 비강 패킹을 제거한 뒤 내시경 검사
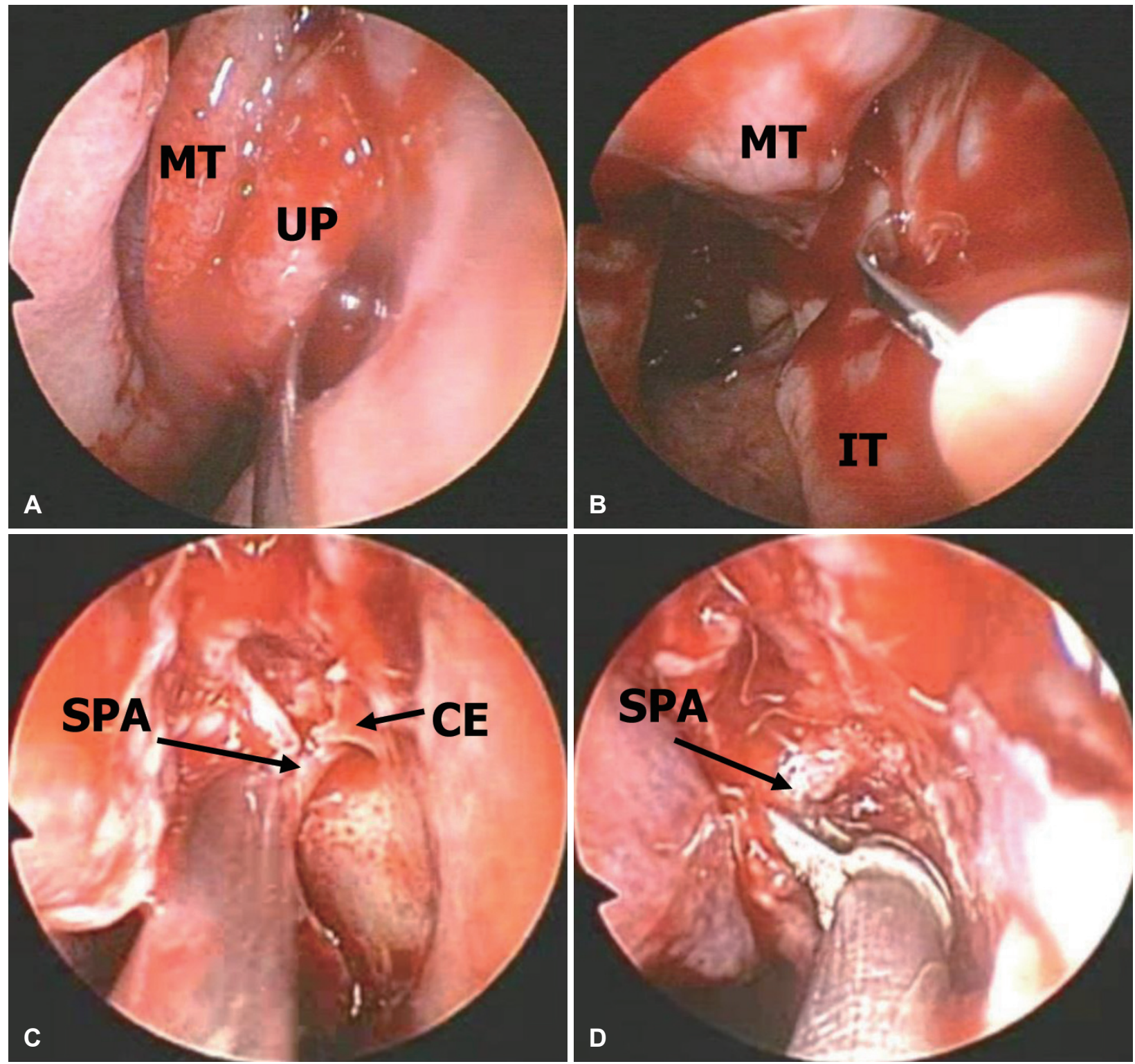

Fig. 1. Procedures of endoscopic SPA ligation. (A) uncinectomy, (B) vertical incision $10 \mathrm{~mm}$ anterior to the posterior attachment of $M T$, (C) identification and partial removal of CE using Kerrison Rongeur, (D) identification and electrocauterization of the main trunk of SPA. MT: middle turbinate, UP: uncinate process, IT: inferior turbinate, SPA: sphenopalatine artery, CE: crista alis. 
를 재시행하였고 중비도에서 출혈 소견이 관찰되어 연고를 도 포한 hydroxylated polyvinyl acetal(IVALON ${ }^{\circledR}$; Fabco, New London, CT, USA)을 좌측 비강내로 삽입하고 생리식염수를 주입하여 팽창시켰다. 이후 즉시 산부인과 협진을 통해 태아의 상태를 모니터링 하였고, 초음파검사상 태아의 이상소견은 관 찰되지 않았다. 비강 패킹 직후 후비루가 멈추는 양상을 보였 으나, 내원 2일째 저녁 환자는 다시 목뒤로 후비루가 넘어가는 느낌을 호소하였고, 구강 검사상 혈성 후비루가 관찰되었다. 당시 심박동수는 $88 \mathrm{bpm}$, 혈압은 $110 / 70 \mathrm{~mm} \mathrm{Hg}$ 로 안정적이 었고 혈색소 $10.1 \mathrm{~g} / \mathrm{dL}$, 혈소판 $228 \times 10^{3} / \mathrm{L}$ 로 내원 당시와 큰 변화를 보이지는 않았다. 환자에게 후비강 패킹이 필요하다는 점을 설명하였으나 환자는 수 일간 반복적으로 발생한 비출 혈 및 비강 패킹으로 인해 심한 스트레스와 피로감을 호소하 고 있는 상태였고, 재출혈 빈도 등을 비롯한 후비강 패킹에 대 한 설명을 듣고 난 뒤 보다 근치적인 다른 치료법을 강력히 원 하였다. 따라서, 산부인과 협진을 통해 태아 모니터링을 시행 하는 한편 마취과의 협조 하에 전신마취 하에 출혈부위 확인 을 시도하였다. 하지만 비강 전체에 걸친 내시경 검사에도 불 구하고 출혈부위를 확인하지 못하여 내시경적 접형구개동맥 결찰술을 시행하였다(Fig. 1). 먼저 좌측 중비갑개 전방 및 후 방 부착부위에 침윤마취를 시행한 뒤 구상돌기 절제술을 시 행하였다. 이후 중비갑개 후방 부착부위 $1 \mathrm{~cm}$ 전방 점막에 수 직절개를 가한 뒤 뒤쪽으로 점막 피판을 거상하였다. 접형구 개동맥의 주간동맥(main trunk) 및 분지 하나를 각각 확인하 였고, 각각에 대해 전기소작술을 시행하였다. 추가적인 분지가 없음을 확인하고 점막 피판을 제 위치로 덮어둔 뒤 수술용 장 갑으로 감싼 IVALON ${ }^{\circledR}$ 으로 좌측 비강 패킹을 한 뒤 수술을 마쳤다. 수술 직후 산부인과 협진을 통해 태아 모니터링을 시 행하여 태아에 이상이 없음을 확인하였고, 조기진통 및 자연 유산의 위험을 낮추기 위해 자궁수축 억제제를 투여하였다. 수술 당일 혈색소는 $8.4 \mathrm{~g} / \mathrm{dL}$, 혈소판은 $175 \times 10^{3} / \mathrm{L}$ 였으며 수 혈을 시행하지는 않았다. 수술 후 2일째 혈색소는 $8.9 \mathrm{~g} / \mathrm{dL}$ 로 상승하였고, 비출혈도 멈추어 비강 패킹을 제거하였으며, 이 후에 더 이상의 비출혈은 발생하지 않았다. 외래 추적관찰 시 수술 후 18 개월 때까지 비출혈 재발 소견은 보이지 않으며 코 막힘 등의 증상이나 비강내 유착과 같은 합병증은 발생하지 않았다.

\section{고 찰}

임신한 여성의 비출혈 이환율은 비 임신 여성에 비해 3배 이상 높은 것으로 알려져 있다.5) 임신 중 비출혈의 위험성을 높이는 원인은 여러 가지이다(Table 1). 먼저 임신 중 혈중 에
Table 1. Obstetric causes of epistaxis

\begin{tabular}{ll}
\hline \multicolumn{1}{c}{ Etiology } & \multicolumn{1}{c}{ Reference } \\
\hline $\begin{array}{l}\text { Estrogen-induced increased vascularity } \\
\text { of nasal mucosa }\end{array}$ & Sobol, et al. ${ }^{7)}$ \\
HELLP syndrome & Sibai \\
Granuloma gravidarum & Zarrinneshan, et al. $^{9)}$ \\
Gestational hypertension & Cornthwaite, et al. ${ }^{10)}$ \\
\hline
\end{tabular}

HELLP: Hemolysis, Elevated Liver enzymes, Low Platelets

스트로겐 농도가 상승하면 비 점막의 혈관분포가 증가되고 이는 혈관의 울혈과 점막의 부종으로 이어져 비출혈 시 출혈 시간을 늘리는 원인이 된다. ${ }^{7)}$ 임신 중 합병증으로 발생할 수 있는 임신성 고혈압과 Hemolysis, Elevated Liver enzymes, Low Platelets(HELLP) 증후군 역시 비출혈의 위험성을 증가 시키는 원인이다. HELLP 증후군이란 혈소판 감소증이 진행 되어 용혈, 간효소 수치의 증가, 혈소판의 감소가 동반되는 경 우를 가리키며, 산모와 태아 모두에게 매우 치명적일 수 있으 므로 반드시 응급 분만이 요구되는 질환이다. 따라서 혈소판 감소증을 보이는 산모는 반드시 간효소 검사와 말초혈액도말 검사로 HELLP 증후군을 감별해야만 한다.8) 이외에 임신성 육아종도 비출혈을 일으킬수 있다. 임신성 육아종은 임산부 의 약 2 5\%에서 드물게 발생하는 화농성 육아종으로 임신 중 다량의 비출혈을 일으킬 수 있다.") 본 증례의 산모는 임신 전과 임신 기간 중 모두 정상 혈압을 보여 임신성 고혈압은 배 제가 되었고, 비출혈 발생 전후 및 수술 이후의 혈소판 수치 모두 정상범위를 보였으며, 간효소 수치도 증가하지 않아 HELLP 증후군에 의한 비출혈도 배제가 되었다. 비강에 임신 성 육아종으로 의심되는 소견은 보이지 않았고 다른 임신 이 외에 비출혈의 위험 요인도 발견할 수 없었다. 이렇게 뚜렷한 위험 요인이 없는 임산부에서 보존적 치료에 반응하지 않는 심한 비출혈은 세계적으로도 매우 드물지만 발생할 수 있고, 본 증례를 비롯하여 2013년 영국에서 보고된 증례에서 볼 수 있듯이 산모나 태아에 특별한 합병증 없이 수술로 치료될 수 있으므로 보존적 치료에 실패하는 경우 내시경적 접형구개동 맥 결찰술과 같은 수술적 치료를 적극적으로 고려할 필요가 있겠다. ${ }^{10)}$

임산부에서 심한 비출혈이 발생하게 되면 비 임신 환자에 비해 치료에 있어서도 제한이 따른다. 비강 패킹 시 사용하는 예방적 항생제 역시 산모에게는 제한적으로 사용해야 하나 penicillin, cephalosporin, erythromycin은 임신 중인 여성에 게 안전하게 사용이 가능한 것으로 알려져 있다.11) 본 증례의 경우에도 1세대 cephalosporin인 cefazolin을 정맥 투여하였 으며 이로 인한 산모와 태아에 특별한 문제가 발생하지는 않 았다. 또한, 전비강 패킹이 실패할 때 흔히 고려하는 후비강 패 킹도 임산부에서는 쉽지 않은 선택이다. 후비강 패킹의 경우 
재출혈이 $26 \%$ 에서 $52 \%$ 정도에서 발생하는 데다 유착, 협심증, 안구 봉와직염, 부비동염, 독성쇼크증후군, 저산소증 등의 합 병증 빈도도 $69 \%$ 에 이르는 것으로 알려져 있다. 게다가 후비 강 패킹 자체로 인해 환자가 겪는 스트레스가 커서 이에 따른 태아 스트레스가 커질 수 있다. 실제로 본 증례의 경우도 의료 진이 후비강 패킹을 먼저 권유하였지만 환자가 수일간 반복적 으로 발생한 비출혈과 전비강 패킹으로 인해 극심한 스트레 스와 피로감을 호소하면서 패킹이 아닌 보다 근본적인 치료를 강력히 원하였다. 비록 전신마취가 필요하지만 내시경적 접형 구개동맥 결찰술은 후비강 패킹과 비교했을 때 $90 \%$ 내외의 높은 성공률과 낮은 합병증 발생률을 보이므로 ${ }^{12)}$ 저자들은 산부인과와 마취통증의학과의 협진 하에 전신마취 하 비내시 경 검사를 시행한 뒤 출혈부위가 확인되면 소작술을 시행하 고, 출혈부위를 발견하지 못하는 경우에는 내시경적 접형구개 동맥 결찰술을 시행하기로 하였다. 내시경적 접형구개동맥 결 찰술은 과거에 이용됐던 외경동맥 결찰술, 내악동맥 결찰술보 다 출혈지점에 더 가까이 있는 혈관을 결찰하여 측부 혈행의 발생이 덜해 재출혈의 빈도가 낮고, 술 후 재원 기간이 짧으며, 이환율이 낮은 장점이 있다. ${ }^{13,14)}$ 다만, 임신 중 수술 및 마취를 받은 임산부는 조기진통 및 자연유산의 위험성이 있다고 알려 져 있으므로 술 후 이를 평가하기 위한 자궁감시 및 적극적인 자궁수축 억제제 사용이 필요하다. ${ }^{15)}$ 따라서 본 증례에서도 수술 직후 태아 초음파 검사를 시행하여 태아에 이상이 없음 을 확인하였고, 자궁수축의 위험성을 억제하기 위해 자궁수 축 억제제를 투여하였다.

본 증례와 같이 임산부에서 보존적 치료로 잘 조절되지 않 는 심각한 후방 비출혈은 임상의에게 많은 고민을 안겨준다. 일반적으로 전비강 패킹이 실패하는 경우 후비강 패킹을 먼저 고려하지만 후비강 패킹의 높은 재발률과 저산소증과 같은 합 병증에 의한 산모와 태아의 위험을 고려하면 비록 전신마취에 의한 조산의 위험은 있지만, 내시경적 접형구개동맥 결찰술을
포함한 전신마취 하에 수술을 조기에 고려하는 것도 좋은 치 료 전략이 될 수 있을 것으로 생각된다. ${ }^{15)}$

\section{REFERENCES}

1) Viehweg TL, Roberson JB, Hudson JW. Epistaxis: diagnosis and treatment. J Oral Maxillofac Surg 2006;64(3):511-8.

2) Sessions RB. Nasal hemorrhage. Otolaryngol Clin North Am 1973; 6(3):727-44.

3) Klotz DA, Winkle MR, Richmon J, Hengerer AS. Surgical management of posterior epistaxis: a changing paradigm. Laryngoscope 2002; 112(9):1577-82.

4) Wurman LH, Sack JG, Flannery JV Jr, Paulson TO. Selective endoscopic electrocautery for posterior epistaxis. Laryngoscope 1988;98(12):1348-9.

5) Dugan-Kim M, Connell S, Stika C, Wong CA, Gossett DR. Epistaxis of pregnancy and association with postpartum hemorrhage. Obstet Gynecol 2009;114(6):1322-5.

6) Howard DJ. Life-threatening epistaxis in pregnancy. J Laryngol Otol 1985;99(1):95-6.

7) Sobol SE, Frenkiel S, Nachtigal D, Wiener D, Teblum C. Clinical manifestations of sinonasal pathology during pregnancy. J Otolaryngol 2001;30(1):24-8.

8) Sibai BM. Diagnosis, controversies, and management of the syndrome of hemolysis, elevated liver enzymes, and low platelet count. Obstet Gynecol 2004;103(5 Pt 1):981-91.

9) Zarrinneshan AA, Zapanta PE, Wall SJ. Nasal pyogenic granuloma. Otolaryngol Head Neck Surg 2007;136(1):130-1.

10) Cornthwaite K, Varadharajan K, Oyarzabal M, Watson H. Management of prolonged epistaxis in pregnancy: case report. J Laryngol Otol 2013; 127(8):811-3.

11) Crider KS, Cleves MA, Reefhuis J, Berry RJ, Hobbs CA, Hu DJ. Antibacterial medication use during pregnancy and risk of birth defects: national birth defects prevention study. Arch Pediatr Adolesc Med 2009;163(11):978-85.

12) Schwartzbauer HR, Shete M, Tami TA. Endoscopic anatomy of the sphenopalatine and posterior nasal arteries: implications for the endoscopic management of epistaxis. Am J Rhinol 2003;17(1):63-6.

13) Snyderman CH, Goldman SA, Carrau RL, Ferguson BJ, Grandis JR. Endoscopic sphenopalatine artery ligation is an effective method of treatment for posterior epistaxis. Am J Rhinol 1999;13(2):137-40.

14) Christmas DA, Yanagisawa E, Pastrano JA. Transnasal endoscopic ligation of the sphenopalatine artery. Ear Nose Throat J 1998;77(7):524-5.

15) Leicht $\mathrm{CH}$. Anesthesia for the pregnant patient undergoing nonobstetric surgery. Anesthesiol Clin No Am 1990;8:140. 